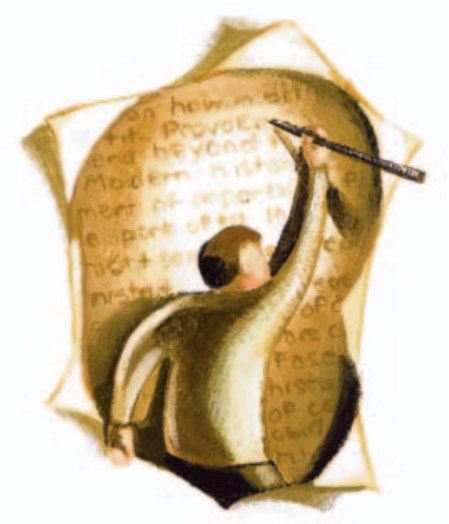

\section{Reflections on the birth of}

\section{conjoined twins}

How refreshing it was to read Ken Walker's article. ${ }^{1} \mathrm{He}$ has the courage to speak out on a subject from which most of us shy away. The major concern of physicians since the time of Hippocrates has been to help prevent pain and suffering; the concept of saving lives at all costs is a modern aberration. In the time of Hippocrates, deformed or malformed babies were put out on the hillside to perish. Of course such a practice would be abhorrent today, but one has to reflect on the enormous cost to our current system of performing heroic procedures on patients whose viability is doubtful.

\section{Glanville Davies BSc MB BCh Surrey, BC}

Competing interests: None declared.

\section{REFERENCE}

I. Walker K. The tragedy that should never have happened. $C M A J$ 2007;177:312.

DOI:I0.I503/cmaj.I070I24

Doctors have one duty to fulfill above all others: the alleviation of suffering. Implicit in this duty is the attempt to correct all forms of malady, including the gestational anomaly leading to the birth of conjoined twins. Abortion in such a case would be a eugenic preemptive strike perhaps based on the hopeless view that medical science will not exceed its current bounds of achievement. Ken Walker's views on the recent birth of twin girls joined at the head in British Columbia ${ }^{1}$ sadly reflect the attitude that such situations are beyond our ability to manage, now and forever. Of course, this would be the case if the trial-and-error approach (the essence of scientific progress) were to be abandoned.

The smiles of the conjoined twins' doctors ${ }^{1}$ reflect hope and courage. Medical anomalies, particularly of this kind, will remain a tragedy only if we abandon our gifts as humans to discover and improve.

\section{Richard F. Poole MB ChB \\ Hudson, Que.}

Competing interests: None declared.

\section{REFERENCE}

I. Walker K. The tragedy that should never have happened. $C M A J$ 2007;177:312.

DOI:I0.I503/cmaj.I070I25

I was interested in Ken Walker's article ${ }^{1}$ as I had just read a discussion of the happiness of conjoined twins in a new book by Harvard psychologist Daniel Gilbert. $^{2}$ Gilbert comments on twins Lori and Reba Schappel, who are joined at the forehead and share a blood supply, part of a skull and some brain tissue. The twins feel that, even were it possible, they would reject surgery to separate them. Gilbert writes, "So here's the question: If this were your life rather than theirs, how would you feel? If you said, 'joyful, playful and optimistic,' ... try to be honest instead of correct. The honest answer is 'despondent, desperate and depressed.' Indeed, it seems clear that no rightminded person could really be happy under such circumstances ... in an exhaustive search of the medical literature, [a] medical historian found the 'desire to remain together to be so widespread among communicating conjoined twins as to be practically universal."” In sum, writes Gilbert, "all claims of happiness are claims from someone's point of view - from the perspective of a single human being whose unique collection of past experiences serves as a context, a lens, a background for her evaluation of her current experience. As much as the scientist might wish for it, there isn't a view from nowhere."

Walker suggests that our concerns about the conjoined twins recently born in British Columbia should be primarily financial in nature. I am moved to quote Kurt Vonnegut, who wrote (in Breakfast of Champions) that a life not worth living combined with an unquenchable will to live is a combination often seen on this planet.

I am glad that Walker is not my doctor, and that he does not have the power to decide who should and who should not be born. Or have that bypass, appendectomy, arthroscopic knee surgery, etc.

After all, we will all end up as worm feed. Timing is, of course, everything.

\section{Beverly R. Akerman MSc}

Professional Writers Association

of Canada

Montréal, Que.

Competing interests: None declared.

\section{REFERENCES}

I. Walker K. The tragedy that should never have happened. CMAJ 2007;177:312.

2. Gilbert D. Stumbling on happiness. Toronto: Vintage Canada; 2006.

DOI:Io.I503/cmaj.I070126

I read with interest the Salon article by Ken Walker. ${ }^{1}$ I am concerned that Walker reduces the discussion about the case of the recent birth of conjoined twins in British Columbia to an argument about the expected health care costs.

In my view, we as physicians should first discuss ethical considerations. The twins' mother refused to have an abortion: Should her physicians or society have forced her to have the procedure without her consent? Now that the twins have been born, to what amount 